Elías Palti

\title{
Koselleck-Foucault: The Birth and Death of Philosophy of History
}

\begin{abstract}
According to Reinhart Koselleck, the period he calls Sattelzeit, which spans from 1730 through 1850, witnessed a crucial conceptual transformation. It was associated with a new, 'modern' way of experiencing temporality, which in turn gave rise to the emergence of the concept of History as a singular collective noun and, consequently, to the philosophies of history. Koselleck's perspective converges, besides, with Michel Foucault's view in The Order of Things, in which Foucault also remarked on the great conceptual break that occurred around 1800 and gave rise to the emergence of what he called the 'Age of History'. However, our attempt at matching Koselleck's Begriffsgeschichte with Foucault's archaeological perspective will also reveal why the former is not yet sufficiently attentive to the diversity of the modes of conceiving of temporality during the four centuries that modernity spans. Lastly, it will allow us to better understand what was the intellectual ground on which the philosophies of history were founded, and also how it eventually became undermined, along with the concept of temporality that was at its basis.
\end{abstract}

I am always terrified when I hear in a few words a whole nation or a time, for what a great multitude of differences does not comprehend the word nation, or the middle ages or antiquity and the modern epoch!

(Johann Gottfried Herder)

Reinhart Koselleck's concept of Sattelzeit has become an inevitable point of reference whenever one seeks to understand the origin of modernity from the perspective of intellectual history. It offers a highly suggestive view of the great conceptual transformation produced between 1750 and 1850-the period he calls Sattelzeit. According to Koselleck, this conceptual transformation was closely associated with a given way of experiencing temporality, which gave rise to the emergence of the concept of History, as a singular collective noun. As he shows, that concept would have been incomprehensible before 1750. To speak of 'History' without further ado, as if it were a kind of macrosubject, would have been simply unintelligible for a person of the fifteenth or even the seventeenth century. The emergence of the philosophies of history was the consequence of this conceptual transformation, as the two were closely tied: as Hein-

Elías Palti, Universidad Nacional de Quilmes (Argentina)

Ә OpenAccess. () 2018 Elías Palti, published by De Gruyter. (cc) BY-NC-ND This work is licensed under the Creative Commons Attribution-NonCommercial-NoDerivatives 4.0 License.

https://doi.org/10.1515/9783110492415-030 
rich Köster then said, "History means the same as historical theory or philosophy of history or as the logic of history" (quoted in Koselleck 2006, p. 74). Historical philosophy thus has a precise historical-conceptual basis, and becomes meaningful only within that given intellectual configuration; it has no meaning outside of it. In short, what this reveals is the contingent nature of the foundations of the philosophies of history, and of the concept of temporality that underlies them.

Koselleck's perspective converges with Michel Foucault's view in The Order of Things (Foucault 1970). In it, Foucault also remarked on the great conceptual break that occurred around 1800 and gave rise to the emergence of what he called the 'Age of History'. Foucault associated it, in turn, with the appearance of a certain concept of 'Subject'. Both concepts (Subject and History) would be closely linked. The latter would be no more than another translation of the former, and ultimately the two are the expression of the new way of experiencing the temporality that both Foucault and Koselleck identify as distinctive of 'modernity'.

However, our attempt at matching Koselleck's Begriffsgeschichte with Foucault's archaeological perspective will also reveal why the former is not yet sufficiently attentive to the diversity of the modes of conceiving of temporality during the four centuries that modernity spans. Actually, it can discern only two possible time-concepts, each of which will be separated by that great epochal rupture that he calls Sattelzeit. This dichotomic perspective leads him to confuse and place under the same category (that of 'modernity') many very different modes of conceiving and experiencing temporality; and this confusion necessarily has consequences in the historical-conceptual recreation he proposed. In short, to perform the very goal of Koselleck's project of a Begriffsgeschichte-of preventing conceptual anachronisms and understanding the intellectual foundations of the philosophies of history-a number of historical precisions are in order.

Foucault was, besides, more emphatic in pointing out the contingent nature of this 'modern' regime of knowledge, in the sense that, for him, it is not only very recent, but also it will not last indefinitely. In fact, he believed we were at the verge of its dissolution. That is what was implicit in his provocative announcement of the imminent 'death of man'. In any case, as we will see in this work, beyond the divergences of their contents, the convergence between Koselleck's conceptual history and Foucault's archaeology of knowledge regarding the nature of the conceptual break produced around 1800 is deeply significant, and the attempt at matching their perspectives will allow us to better understand what was the intellectual ground on which the philosophies of history were 
founded, and also how it eventually became undermined, along with the concept of temporality that was at its basis.

\section{The idea of Sattelzeit and the new consciousness of temporality}

According to Koselleck, the emergence of the philosophies of the history is indicative of a fundamental break with respect to the premodern modes of historical figuration articulated within the frameworks of the Ciceronian concept of historia magistrate vitae. He points out the two premises upon which that pedagogical ideal of history was based. The first of these is the idea of the iterability of history; that is, that the same basic situations are repeated at different times, since only that assumption permits us to draw general laws applicable to every historical epoch. That assumption of the iterability of events made it impossible to conceptualize the idea of 'History' in the singular. What existed, in the context of that perspective, were 'histories', in the plural; that is, a series of situations, events and phenomena, which are eventually repeated in different times, places and circumstances, but which preserve their basic structures and meanings.

The second premise highlighted by Koselleck is that the era of exploration (which opened the horizon of Europeans to the diversity of cultures on the planet) and technological progress finally triggered the crisis of the pedagogical concept of history. Both phenomena combined provide the historical basis for the emergence of the modern idea of 'progress'. Time would then have a directionality, which would make the iterability of history impossible. The future would no longer be readable in the experiences of the past. A gap now divided the 'space of experience' and the 'horizon of expectation'. But the fundamental fact that marked the definitive breakdown of the concept of historia magistrate vitae was the outbreak of the French Revolution, insofar as it affirmed, for Koselleck, the idea of the constructability of history; that is, it engendered a new awareness of the subject's agency. Temporality thus became an immanent dimension-something that subjects unleash with their own action. ${ }^{1}$ As Koselleck points out: "There always occurs in history more or less than that contained in the given conditions. Behind that 'more or less' are to be found men" (Koselleck 1985, p. 212). The modern concept of history would thus arise from the combination of the ideas of progress of the Enlightenment with that of the constructed character of it determined by the revolutionary event.

1 See Hayden White’s “Introduction” in Koselleck 2002, ix-xiv. 
In turn, the temporalization of history would allow us to place in sequential order the cultural diversity that the overseas expansion had revealed; that is, to place diachronically that which appears synchronously. The notion of progress would provide the objective parameter for establishing a 'before' and an 'after', situating each phenomenon as a particular moment in the immanent logic of the development of History. It thus gave rise to the idea of the coexistence of infinite temporalities at each single moment, the simultaneity of the non-contemporary (Gleichzeitigkeit der Ungleichzeitigen). As Herder said in his Metakritik of Kant (a text that Koselleck repeatedly cites as the best synthesis of the 'modern' idea of historical temporality):

In actuality, every changing thing has the measure of its own time within itself.... No two worldly things have the same measure of time. There are therefore (one can state it properly and boldly) at any one time in the universe innumerably many times. ${ }^{2}$

Lastly, the dissolution of the old ideal of historia magistrate vitae forces historical thought to its self-reclusion. To the extent that the temporalization of historical structures prevents generalizations and extrapolations between different epochs, regarding their contents, the idea of historical law can only now refer to the empty forms of temporality; to the transhistorical conditions of change. It is here that Koselleck introduces what he calls the fundamental meta-categories that define the basic forms of historical temporality: 'space of experience' and 'horizon of expectation'. The progressive distance between 'space of experience' and 'horizon of expectation' determines the acceleration of historical time, which is the hallmark of modernity. This allows him to establish a fundamental historical law: the 'law of acceleration', which states that change "occurs at increasingly shorter intervals of time" (Koselleck 1985, p. 314).

In this way, Koselleck reframed intellectual history, insofar as he made it possible to establish a link between conceptual changes and concrete historical experience. However, at this point some of his interpretations demand a number of clarifications and precisions. The question arises of what led him to situate that rupture at a so late moment, which in turn led him to leave out of modernity the whole array of philosophies that emerged in the sixteenth and seventeenth centuries. From this perspective, the line of thought that goes from Descartes to Leibniz, through Hobbes, Locke, Spinoza, Smith, etc. should be considered as 'premodern', since they are all placed before the Sattelzeit; that is, they would be grouped together under the same category as the philosophies of St.

2 Herder, J. G. (1955): Metakritik zur Kritik der reinen Vernunft, p. 68; quoted in Koselleck 1985, p. 247. 
Augustine or St. Thomas, which is clearly untenable. Furthermore, it contradicts what Koselleck himself remarked in his doctoral thesis (written in 1954 and published in 1959), Critique and Crisis (Kosellek 1988). Lastly, that chronological incongruity makes manifest much deeper problems of a conceptual order.

These conceptual problems send us back to the issue of historical temporality. Koselleck actually confuses two completely different concepts of it: the one implicit in the Enlightenment's notion of 'progress'; and the idea of 'evolution', arising only later, during the nineteenth century. It is only along with this latter that time became conceived as irreversible. On the contrary, the most characteristic and determining achievement of the scientific revolution and of the Enlightenment, that many plainly associate with the coming of the so-called 'Modern Age' (although Foucault prefers calling it the 'Classical Age', to distinguish it from the 'Modern Age' whose origins he places, in coincidence with Koselleck's Sattelzeit, around 1800) was precisely the development of the notion of temporal reversibility. This notion was perfectly formulated by Ferdinand Laplace (the leading astronomer of the late eighteenth century, who completed the Newtonian system) and symbolized in his idea of the 'little demon'. He stated that one who was able to know the whole universe in its present state "would have the entire past and the entire future before his eyes." ${ }^{3}$ With this idea, Laplace only led the Newtonian astronomical concept to its ultimate logical consequences. According to it, temporality is not a constituent element of the physical universe. If we could know the exact current position of all planets and stars, we could perfectly know where they were a thousand years ago and where they will be a thousand years from now. The asymmetry between past and future here appears as merely a subjective illusion resulting from the limitations of our cognitive capacities.

The kind of idealization that allowed seventeenth and eighteenth century minds to conceive of the world as lacking a temporality of its own was the culmination of a sustained and prolonged intellectual effort. Irreversibility was, in fact, the most characteristic feature of the medieval-Christian notion of secular time (a notion that did not rule out the possibility of the mutation of living species or the spontaneous generation of new ones). Since every change in the world required providential intervention that marked a radical difference between present and past, the idea of a homogeneous temporal flow was still inconceivable.

The Enlightenment's idea of historical progress as an accumulation of knowledge entailed, instead, continuity; that is, the assumption of a homogeneous human nature providing a unitary substrate for this process. The idea of rad-

3 On Laplace's idea of 'little demon', see: Cassirer 1956, pp. 3-25. 
ical mutation, both in animal species and in cultural processes, was completely foreign to Enlightenment thought. The breakdown of this linear and homogeneous conception of time leads us, in fact, beyond the horizon of the Enlightenment. Foucault's analysis of The Order of Things is revealing in this regard, and allows us to introduce a number of precisions into Koselleck's perspective of the Sattelzeit.

\section{The archaeology of knowledge and the emergence of philosophy of history}

Although Foucault does not make it explicit, it is clear that the aim of The Order of Things was to rebuke the standard view of the link between modernity and subjectivity that was best synthesized by Heidegger in "The Age of the World Picture”, and to introduce into it a fundamental historical precision. Unlike Heidegger, for Foucault the idea of 'subject' that Heidegger believes he finds in Descartes is in fact a later conceptual construction-one that would emerge in the nineteenth century, when the 'Modern Age' (or the 'Age of History', as he calls it) actually began. Foucault's perspective thus converges with Koselleck's in locating the origin of modernity two centuries later than Heidegger does. However, unlike Koselleck's perspective, Foucault's does not ignore the presence of a conceptual break produced around 1600, as Heidegger affirmed, though Foucault disagrees with the latter regarding its content and meaning. He thus introduces a distinction between the two.

In short, Foucault's archaeological perspective is more attentive than Koselleck's to the occurrence of a conceptual break before the Sattelzeit, but, unlike Heidegger, instead of projecting this break back in time, he remarks on the profound difference between the two systems of knowledge to which they respectively gave rise. In this way, Koselleck compels us to revise the dichotomous schemes-the either/or that articulates the entire tradition of the history of ideas and permeates also the perspectives of both Koselleck and Heidegger (either premodern or modern)-leading to the unification of very different forms of thinking under a common label. Yet, as we shall see, we also meet here the fundamental shortcoming in Foucault's archaeology of knowledge. If it is more perceptive of the conceptual transformations produced before the Sattelzeit, it misses other, no less radical, transformations that took place after it. That is, that not all forms of thought and historical views that emerged after 1800 can be considered as equally 'modern'-a lack of acknowledgment of which also leads him to confuse and unify under a common category very different concepts of historical 
temporality. Yet, in order to observe this problem, we must first to go back and see Foucault's archaeological project and, in particular, his criticism of Heidegger's view that associates modernity with the emergence of the concept of 'subject'.

In "The Age of the World Picture", Heidegger elaborated on the etymological roots of the term subjectum. As he says, it is the Latin translation of the Greek term hypokeimenon, to which Aristotle referred in his Physics and Metaphysics. It indicates the substrate of the predication; that which underlies and holds together all its predicates. In principle, all that (either a thing or a living being) of which something could be said is a 'subject'. The identification of the 'subject' with the 'I', initiated by Descartes, is precisely, for Heidegger, what marks the emergence of the modern world. ${ }^{4}$ With modernity, man becomes the premise for the intelligibility of the world, which is then reduced to the condition of merely a material for its action.

This entailed, for Heidegger, a fundamental conceptual rupture. Man then separates from the world and becomes the one who represents it and provides a meaning to it. In the Middle Ages, man and world were only different phases in the plan of Creation; the two participated in the order of correspondences of what is, which always referred back to their ultimate Cause (God). In antiquity, the world was not something to which the subject represented, but something that presented itself, which was shown to the subject and, ultimately, it was in the act of disclosing itself that it was constituted as such. Man and world thus co-belonged in the repraesentatio (etymologically, to become present) of what exists.

In The Order of Things, Foucault both discusses and takes on this concept, introducing to it a fundamental distinction. What he calls the 'classical' episteme (of whose emergence Don Quixote serves as a symbol and expression) was born, in effect, out of the break of the order of correspondences. In the regime of knowledge that dominated until the sixteenth century, all that existed (the chain of being), including language, was conceived as the visible mark of that hidden force that constituted them and rendered them visible. The space of similarities would form a system of 'signatures' for the unveiling of the hidden plan of Creation. As Heidegger said, in this system of knowledge the world shows itself, and "all that remains is to decipher it" (Foucault 1970, p. 27).

4 "However, when man becomes the primary and only real subjectum, that means: Man becomes that being upon which all that is, is grounded as regards the manner of its Being and its Truth. Man becomes the relational center of that which is as such" (Heidegger 1977, p. 128). 
By the end of the sixteenth century, that natural link-by which the visible immediately refers back to its last, hidden source-is broken, and words are distanced from things. Language becomes an artifice to articulate the whole out of the fragments deployed on the surface of the visible forms. The subject now has the task of reconstructing the logic of their dispersion of forms in the play of their similarities and differences. Things, then, no longer speak of anything beyond them, but refer to each other, tied as they are to the ground of Order that distributes them in the world and connects them with each other.

However, within the framework of this episteme, Foucault points out, there was still no place for any idea of 'subject' nor, ultimately, for the notion of temporal irreversibility (nor, therefore, of History in the singular). Foucault refers here to the expression with which Hegel opens his Phenomenology of Mind: "everything depends on grasping and expressing the ultimate truth not as Substance but as Subject as well” (Hegel 2003, p. 9). The 'subject' referred to here -which is no longer merely substance, as it was in classical times-is a reflexive concept; an in-itself and for-itself.

Only in light of this could we properly speak of a modern Subject (and, ultimately, a modern episteme), at least in the sense attributed by Foucault: that type of Being whose interiority gives rise to History, constituting a dimension inherent in it. It is, more precisely, the premise for the conceptual transformation analyzed by Koselleck under the rubric of Sattelzeit. The Subject, unlike the Substance, is no longer merely the substrate of predication (that which remains immutable below the changes of form imposed upon it) but a dynamic force; what defines it as such is the fact of containing within itself the principle of its own transformations. This conceptual redefinition is closely linked, in turn, to the emergence of the idea of the living organism as associated with the capacity for self-generation and self-development, which marks the transition from the 'natural history' of the classical age to modern 'biology'. The point here is that the emergence of this concept marks a rupture no less crucial than that which occurred two centuries earlier with the break of the system of correspondences. Heidegger thus confused two conceptions of subjectivity (and temporality) very different from each other, placing both under the common label of 'modern subject'. Lastly, he would project back towards the sixteenth century a concept that would only emerge at the end of the eighteenth century. The passage from the 'natural history' of the Enlightenment to 'biology' illustrates how this later conceptual transformation occurred.

The idea of the subject in the classical era was forged in a fixist-preformationist matrix of thinking, which was at the basis of the 'natural history' of the Enlightenment. The preformationist concept of the organism, which emerged in the sixteenth century and dominated the natural thought of the seventeenth 
and eighteenth centuries, asserted that the forms of adult individuals were preformed in the embryo. The gestation process was only the growing up of traits and forms already discoverable in the origin of that process. The fact is that only that hypothesis made possible the idea of an immanent, self-generated development. Only the developments produced in the early nineteenth century in the field of embryology provided a new model of 'organic' evolution. Karl Ernst von Baer (the 'founding father' of modern embryology) is the key figure in this process of conceptual redefinition. According to the theory formulated in his History of the evolution of animals (1828 and 1837), what would be preformed in the embryo would no longer be a set of visible traits, but the principle for the formation of them; that is, a certain logical order of coordinated transformations oriented towards the realization of an immanent purpose (something similar to what we call a 'genetic program'). Time, then, would no longer be a circumstance external to beings but a dimension intrinsic to them. The 'subject' would then come to designate this compound, that which displays a temporality by itself, placing itself beyond the plane of visible forms as its hidden formative force. And this explains one of the phenomena that Koselleck points out in relation to the modern philosophies of history: the idea of the coexistence of plurality of temporalities. It is here also where Koselleck's confusion between progress and evolution becomes more manifest, which leads him to misinterpret Herder's expression.

For Koselleck, the idea of the simultaneity of the non-contemporary that he (erroneously) attributes to Herder arises from the possibility of ordering the variety of realities existing in space in a linear sequence of development. As he affirms, the idea of historical progress allows us to identify what comes 'before' and what 'after'. This, in fact, is the premise that lies at the base of the Enlightenment notion of the coexistence of pluralities of temporalities-but not of evolutionary thought. When Herder said that "In actuality, every changing thing has the measure of its own time within itself... [and that therefore] no two worldly things have the same measure of time" ${ }^{\text {, }}$, he was precisely denying the possibility of establishing any absolute temporal criterion-an objective parameter that allowed distinguishing the former from the later. The plurality of temporalities derived from the fact that, for him, there was not an empty becoming; a purely objective temporality, independent of something (a subject) that evolves. Time becomes a dimension intrinsic to the subject; it is something that 'comes to beings from within', to put it in Foucault's words-a function of the differential evo-

5 Herder, J. G. (1955): Metakritik zur Kritik der reinen Vernunft, p. 68; quoted in Koselleck 1985, p. 247. 
lutionary process of organisms. In short, there is not a single (objective) temporality, but as many temporalities as existing beings. We find here the nucleus of the historicist concept. History thus becomes a reflexive concept; an in- and foritself; that is, a 'Subject' (which is no longer 'Substance', according to Hegel).

As we can see, within the period that Koselleck designates as Sattlezeit, two very different views of time coexist. Yet, there is a third concept of it that becomes collapsed under the brand of 'modern time'. The definition of the idea of the 'constructability' of history that then arises has a very different meaning from that which Koselleck believes to find there. This leads us to introduce a second historical precision. His view of the relativity of time actually emerged later, and corresponds to a subsequent moment in intellectual history. Here too, Koselleck's dichotomous interpretative scheme pays its price, since it again leads him to confuse another very different concept of historical temporality, besides the two mentioned above, grouping all three of them under the common category of 'modernity'. Actually, within his perspective, we cannot think of the possible existence of conceptual changes in the modes of experiencing historical temporality, except in terms of the antinomy premodern/modern. In fact, the fundamental law which, for him, governs the whole conceptual history of the modern age-the 'law of acceleration of time'-allows us to perceive only quantitative differences; it would be only a matter of degree: what changed between the eighteenth and nineteenth centuries would be the measure of the interval of time in which change occurs, and the same between the nineteenth and twentieth centuries, and so on. However, unlike the previous historical precision (between the ideas of 'progress' and 'evolution'), Foucault no longer serves as a guide to understand how this new break occurred at the end of the nineteenth century.

\section{The end of the 'Age of History' and the 'Death of the Subject'}

In the concept of History that arose in the nineteenth century (which is the one that Koselleck analyzes), change and permanence are combined in a particular way. Although for nineteenth-century evolutionary thought every fact was absolutely singular (that is, unlike historia magistrate vitae, history now never repeats itself), it did not mean that the future was not somehow contained in germ form in the present as an immanent telos. It was thought that, in the same way as the present is born out of the past, the future must also be somehow already contained in it as one of its potential alternatives of development. This imposed strict limits to the 'constructability' of history. That the subject 'constructs' His- 
tory does not mean that its action does not obey, in turn, a more general evolutionary logic that encompasses it. This is precisely what paved the way in the nineteenth century to the thinking of History as a system (and led Hegel to speak of 'the work of history'). It would be even more appropriate to say that, within this concept, it is History that makes man, rather than the other way around. A 'stronger' view of temporality founded on the assumption of subjective agency involved the absolute contingency of historical development; that is, the radical constructivism of history. This view only emerged at the end of the nineteenth century, with the break of the evolutionary pattern that dominated the preceding century. The emergence of this new view of time marked a conceptual rupture no less profound than that produced in the period that Koselleck called Sattelzeit.

Ultimately, Koselleck incurs a conceptual anachronism: just as Heidegger projects onto the sixteenth century a concept of the subject that only emerges in the nineteenth century, Koselleck projects onto the end of the eighteenth century a concept of historical temporality that actually emerged later, in the twentieth century. Koselleck's idea of historical thinking as referring to an empty structure of temporality is the result of the break of the evolutionary concept of history. The idea of the radical contingency of evolutionary processes then permeates the entirety of Western thinking, crossing through the 'great divide' between natural and social sciences. We see here the horizon of thought from which Koselleck's very historical perspective emerged-and that he projects back in time to the nineteenth century.

By the end of the nineteenth century, the view of systems as containing within them an immanent purpose-the unity between system and end-had broken, and only thus the idea of the radical indeterminacy of history was born, and its cognate concept of the agency of the subject along with it. The conceptual crisis produced at the end of the nineteenth century thus offers the ultimate framework for understanding the meaning of the intellectual project around which Koselleck's own work unfolds. Here too, the reference to a series of developments produced in the field of natural sciences reveals the emergence of that new paradigm of temporality.

A then-newly emerged discipline, electrodynamics, is indicative of the transformations occurred in the modes of thinking the historicity of physical, and, by extension, social systems. In the theory developed by Maxwell and Faraday, magnetic fields are no longer mere aggregates of elements, but sets of relations that form integrated systems of interacting forces. These systems appear as constellations of elements whose composition and recomposition are spontaneous and sudden, without obeying any genetic pattern of progressive formation. The notion of totality (structure) was then detached from that of purpose (function), 
thus dissociating diachrony from synchrony, the evolutionary processes from the inherent dynamics of systems, which would be oriented solely towards their selfreproduction, the perpetuation of their own internal balance or homeostasis.

A convergent path was followed by different disciplines, like biology. In 1900, Hugo de Vries gave the final blow to the nineteenth-century holistic-functionalist conceptions of evolution, paving the way to the formulation of the theory of the 'Great Synthesis'. For de Vries, evolutionary phenomena at the phylogenetic level result from sudden transformations or random global mutations. In this way, mutations (change) are reduced to unpredictable, internally generated occurrences, but with no perceivable goal or purpose: even though they serve an adaptive process of the species to their environment, selection occurs only $a$ posteriori, without any immediate impact on genetic processes themselves.

These developments, as mentioned, contributed the rise of a new paradigm of time. Non-teleologically ordered processes, insofar as they involve the occurrence of the sudden recombination of elements, break the linearity of the developments of matter. Each discreet moment in the sequence of the transformations operated in a system introduces a real novelty; that is, it entails the total reconfiguration, according to a new and peculiar arrangement, of its constituent elements. Only then does the problem of the agential character of the historical subject emerge.

From the moment that systems lose any inner teleological impulse, any principle to their self-transformation, change, or contingency could only come from an instance transcendent to them; it would be the emanation of a Being that preexists them, and allegedly institutes them. We thus get Koselleck's claim that: "there always occurs in history more or less than that contained in the given conditions. Behind that 'more or less' are to be found men” (Koselleck 1985, p. 212). The subject's action, which until then had served as the guaranteed for the rationality of the sequential order of historical transformations, now appeared, on the contrary, as introducing an element of 'irrationality' that breaks the linearity of properly 'historical' processes-a concept that now, but only now, became associated with the idea of radical contingency. The ambiguous relationship between Koselleck's idea of modernity and that of his master, Heidegger, is particularly significant in this respect.

The claim that behind all historical change lies intentional action would be, in principle, taking on the Heideggerian notion of modernity as the era in which man becomes the subjectum. However, if we look closely at Koselleck's claim, the 'modern' subject to whom he refers no longer has anything in common with the one of which Heidegger spoke. It rather meant its complete reversal. The self is no longer a subjectum, the unitary substrate that underlies the changes of form that are imposed upon it, but, on the contrary, the origin and source of contin- 
gency in history. In short, within the new episteme that was born at the end of the nineteenth century, in whose framework there emerged the concept of subjectivity that Koselleck retrospectively attributes to modernity as a whole, the transcendental subject (intentional action) is no longer a guarantee of order, and becomes the one that destroys all identity in history, which breaks the linearity of evolutionary processes and makes the radically new to emerge-that which cannot be thought from the present 'space of experience'. In sum, it gave rise to that which was unthinkable not only within the frameworks of the Enlightenment's idea of 'progress', but also of nineteenth-century's evolutionary concept: the radical contingency of historical developments. ${ }^{6}$

As we see, Koselleck's account fails to avoid relapsing into the kind of anachronisms that he attempted to prevent. This inevitably has consequences in his historical recreation of the origins of modernity. On the one hand, it leads, as we have observed, to establishing a too drastic distance between the first modern philosophies of history and the Ciceronian pedagogical ideal of it; and, on the other hand, it confuses very divergent social and historical imaginaries, placing them all under one common category (that of modernity). In fact, as I have already pointed out, its fundamental law for understanding modern temporality-that of 'acceleration of time'-makes inconceivable the possible emergence of other ways of experiencing temporality that are qualitatively different to that which is at the basis of the concept of History that emerged in the late eighteenth and the early nineteenth centuries.

However, it is clear that these historical-conceptual precisions are only possible within the horizon opened by Koselleck's own historical-conceptual project. Ultimately, the point toward which the history of concepts and the archeology of knowledge converge (and of which that requirement of conceptual rigor is only a by-product) consists in the fact that they introduce a displacement of the locus of reflection. They cease to be philosophies of history, different to the rest but placed on their very same terrain, and become meta-philosophies of history; their emergence represents a turn to a second-order level of historical consciousness, which no longer seeks to discover a meaning in history, but rather to understand what were the precise historical-epistemological conditions that led to imagining such a project-the historical-conceptual conditions for the inception of the very philosophies of history; in short, to recreate the underlying substrate of thinking upon which they were historically based, and how the particular concept of temporality implicit in them eventually became undermined.

6 On the difference between the concepts of time in the philosophies of history of Romanticism and Neokantianism, see: Palti 1977. 
These theories can no longer be considered as philosophies of history, and indeed render it no longer possible to think of them. From the moment in which they seek to disclose the fact that philosophies of history are situated within a particular regime of knowledge, and therefore lack meaning if they are detached from it, they move reflection to a plane already completely alien to that which was proper to them. In short, they mark a turning point that renders impossible a regression to the kind of idealizations on the basis of which philosophies of history rested, and which currently have lost their symbolic ground. Doing so today would entail a kind of historical naivety, or, more precisely, a certain historical-conceptual blindness to the epistemic conditions on which the historicalphilosophical discourse itself is founded; the contingent nature of the regime of knowledge within-and only within-which they became meaningful. Once it has become undermined, they lose any substantive sense, in historical-conceptual terms.

\section{Bibliography}

Blumenberg, Hans (1999): Die Legitimität der Neuzeit. Erneuerte Ausgabe. Frankfurt am Main: Suhrkamp.

Brunner, Otto / Conze, Werner / Koselleck, Reinhart (Eds.) (1972-1997): Geschichtliche Grundbegriffe. Historisches Lexikon zur politisch-sozialen Sprache in Deutschland. 9 vols. Stuttgart: Klett-Cotta.

Cassirer, Ernest (1956): Determinism and Indeterminism in Modern Physics. New Haven: Yale University Press.

Foucault, M. (1970): The Order of Things. An Archaeology of Human Sciences. New York, Vintage.

Hegel, F.G.W. (2003): Phenomenology of Mind. New York: Dover.

Heidegger, Martin (1977): “The Age of the World Picture”. In: The Question Concerning Technology. New York: Harper Torchbooks.

Koselleck, Reinhart (1985): Futures Past. On the Semantics of Historical Time. Cambridge, (MA): MIT Press.

Koselleck, Reinhart (1988): Critique and Crisis. Enlightenment and the Pathogenesis of Modern Society. Oxford, Berg: MIT Press.

Koselleck, Reinhart (2002): The Practice of Conceptual History, Timing History, Spacing Concepts. Stanford: Stanford University Press.

Koselleck, Reinhart (2006): Begriffsgeschichten. Studien zur Semantik und Pragmatik der politische und sozialen Sprache. Frankfurt am Main: Suhrkamp Verlag.

Palti, Elías (1997): “Time, Modernity, and Time Irreversibility”. In: Philosophy and Social Criticism XXIII.5, pp. 27-62.

Palti, Elías (2004): “The 'Return of the Subject' as a Historico-Intellectual Problem”. In: History and Theory 43, pp. 57-82. 